\title{
Peningkatan Penguasaan Kosakata Bahasa Inggris melalui Penggunaan Teknik Think Pair Share (Studi pada Mahasiswa Program Pendidikan Bahasa Inggris Universitas Nahdlatul Ulama Blitar)
}

\author{
Istina Atul Makrifah ${ }^{1}$ \\ ${ }^{1}$ Universitas Nahdlatul Ulama Blitar \\ Email: ${ }^{1}$ istina.atulmakrifah@gmail.com
}

\begin{tabular}{l}
$\overline{\text { Tersedia Online di }}$ \\
\hline http://www.jurnal.unublitar.ac.id/ \\
index.php/briliant
\end{tabular}

Sejarah Artikel

Diterima pada 28 Februarit 2018

Disetuji pada 29 Maret 2018

Dipublikasikan pada 13 Mei 2018

Hal. 148-154

\section{Kata Kunci:}

peningkatan, kosakata, teknik think pair-share

\section{DOI:}

http://dx.doi.org/10.28926/briliant .v3i2.157

\begin{abstract}
Abstrak: Hasil analisis yang dilakukan oleh peneliti menunjukkan bahwa kurangnya penguasaan kosakata Bahasa Inggris pada mahasiswa semester 1 Universitas Nahdlatul Ulama Blitar perlu diatasi dengan penggunaan teknik yang tepat yakni Think Pair Share. Perlunya peningkatan keaktifan mahasiswa sebagai pusat pembelajaran perlu ditingkatkan. Penelitian ini bertujuan untuk meningkatkan penguasaan kosakata Bahasa Inggris pada mahasiswa dan menyediakan teknik yang tepat diterapkan pada pembelajaran kosakata. Terdapat 2 siklus yang dilakukan dengan hasil siklus I rata-rata kelas sebesar 60 dan meningkat di siklus II sebesar 71,15 yang sudah mencapai kriteria keberhasilan. Selain dari hasil nilai, siswa mengalami perubahan sikap lebih aktif, fokus dalam analisis.
\end{abstract}

Pada era globalisasi dan teknologi, masyarakat dituntut memiliki kemampuan berbahasa inggris yang baik. Terlebih pada perguruan tinggi di Indonesia, Bahasa Inggris sangat penting dipelajari dan dikuasai tidak hanya oleh mahasiswa tetapi juga tenaga pendidiknya. Begitu pula pada program studi pendidikan Bahasa Inggris Universitas Nahdlatul Ulama Blitar yang mempunyai tujuan utama mencetak lulusan berkarakter yang mempunyai kompetensi unggul di bidang pendidikan maupun ilmu Bahasa Inggris. Para lulusan program studi pendidikan Bahasa Inggris dipersiapkan agar memiliki daya saing dengan jurusan yang sama maupun berbeda.

Pengembangan kompetensi mahasiswa juga ditunjang dengan diberikannya mata kuliah vocabulary dimana matakuliah ini membantu mahasiswa untuk mengembangkan kosakata Bahasa Inggris yang dipakai dalam komunikasi baik lisan maupun tulisan. Seperti yang dikemukakan Cahyono \& Widiati (2011: 107) menyatakan bahwa menguasai kosakata membantu dalam menguasai semua ketrampilan bahasa. Penguasaan kosakata yang banyak dapat meningkatkan pula kemampuan mahasiswa dalam semua ketrampilan berbahasa Inggris seperti berbicara, mendengar, membaca maupun menulis. Seperti yang diungkapkan oleh Hudson (2007: 227), mempelajari kosakata adalah kunci dalam bahasa dan pemerolehannya. Sehingga agar dapat menggunakan bahasa dengan baik, seseorang perlu dibekali oleh kosakata yang memadai. Terlebih Grabe (2009:283) pembelajaran kosakata perlu dikembangkan dari gabungan instruksi 
kosakata secara langsung, strategi pembelajaran kosakata, membaca ekstensif dan pembelajaran kata dari konteks, peningkatan kesadaran siswa dari kata baru, dan motivasi untuk menggunakan dan mengumpulkan kata-kata.

Subjek pada penelitian ini merupakan mahasiswa program pendidikan Bahasa Inggris di semester 1. Mahasiswa memiliki sedikit kosakata Bahasa Inggris sehingga menghambat dalam berkomunikasi dan mengungkapkan ide. Dapat dilihat dari hasil lembar pekerjaan mahasiswa yang memiliki kekurangan dalam memilih kosakata maupun pengembangan kosakata dalam kalimat yang benar. Selain itu, pada proses pembelajaran, siswa kurang aktif di kelas. Sedikitnya kosakata yang dimiliki mahasiswa juga menghambat mereka dalam berkomunikasi, menafsirkan makna dalam membaca maupun mendengarkan serta menggabungkan ide dalam menulis essay. Terlebih kosakata bahasa inggris yang memiliki lebih dari satu makna yang menyebabkan multitafsir. Penguasaan kosakata yang banyak dapat membantu mahasiswa lebih aktif menggunakan Bahasa Inggris baik lisan maupun tulisan.

Melihat beberapa permasalahan-permasalahan tersebut, maka pengajar merefleski kegiatan pembelajaran yang telah dilakukan di kelas dengan melakukan inovasi dalam hal penggunaan metode pembelajaran yang membantu mahasiswa.

Peneliti melakukan Penelitian Tindakan Kelas dengan menerapkan teknik Think pair Share untuk menanggulani masalah-masalah yang ada di kelas. Kagan (2009:14.8) teknik Think Pair Share merupakan salah satu model pembelajaran cooperative learning yang terdiri dari 3 langkah yaitu Think (berfikir), Pair (berpasangan), dan Share (berbagi). Metode ini membantu mahasiswa dalam mendapatkan dan menguasai kosakata dengan berkelompok dan saling koreksi (peer editing). Melalui teknik tersebut, diharapkan dapat meningkatkan penguasaan kosakata Bahasa Inggris mahasiswa program Pendidikan Bahasa Inggris Universitas Nahdlatul Ulama Blitar.

\section{METODE}

Penelitian ini merupakan Penelitian Tindakan Kelas untuk memperbaiki permasalahan pembelajaran yang ada dikelas. Data disajikan dalam bentuk kualitatif yakni didiskripsikan melalui kata-kata tentang bagaimana teknik diterapkan dan bagaimana hasil yang didapat. Selain itu, juga disajikan dalam data kuantitatif dengan table hasil belajar mahasiswa.

Subjek dari penelitian ini merupakan mahasiswa Program Pendidikan Bahasa Inggris Semester 1 Universitas Nahdlatul Ulama Blitar. Terdapat 26 mahasiswa yang terdiri dari 12 laki-laki dan 14 perempuan.

Penelitian ini dilakukan melalui 2 siklus dimana setiap siklus terdiri dari 2 pertemuan dengan tahapan yang sama yakni perencanaan, pelaksanaan, pengamatan dan refleksi. Tahapan tersebut akan diulang apabila dalam siklus pertama tidak mencapai hasil yang memuaskan.

Data kualitatif didapatkan dari lembar pengamatan yang diisi oleh observer dan wawancara. Lembar pengamatan diisi untuk mengevaluasi proses pembelajaran di kelas. Selain dengan mencentang, dilakukan pula pencatatan halhal yang dianggap penting. Sedangkan data kuantitatif didapat dari tes yang dilakukan di akhir pertemuan setiap siklus 
Instrumen pembelajaran berupa RPS, RPP, materi pembelajaran "root dan affixes serta derivational dan inflectional affixes", serta teks yang dianalisa dan didiskusikan dengan judul "Reading Skills, Vocabulary in Second Language Reading, Wrap-Up of Second Language Reading: Teaching Issues, dan Reading and Second Language Vocabulary Learning".

Setelah data terkumpul maka peneliti mereduksi data sesuai kepentingan yang dibutuhkan. Menyusun data yang sudah dipilih dengan keterkaitannya meningkatkan kosakata mahasiswa. Hal terakhir dari menganalisis data adalah menyimpulkan hasil data yang diperoleh.

\section{HASIL}

\section{Siklus I}

\section{Perencanaan}

Dalam perencanaan, peneliti melaksanakan sebagai berikut: menyiapkan instrument pembelajaran yaitu RPP, dan materi dengan tema root dan affixes (kata berimbuhan), menyiapkan instrument pengamatan berupa lembar pengamatan proses pembelajaran di kelas, wawancara dan tes untuk mengukur penguasaan kosakata mahasiswa.

\section{Pelaksanaan}

Pembelajaran siklus I dilaksanakan pada 8 \& 15 Desember 2017 dengan alokasi waktu $2 \times 50$ menit. Terdapat 2 teks yang akan dianalisa yakni "Reading Skills" dan "Vocabulary in Second Language Reading".

Pelaksanaan proses pembelajaran dengan teknik Think-Pair-Share dilakukan dengan memperbaiki masalah yang ada di kelas dan meningkatkan keaktifan mahasiswa dalam proses pembelajaran. Terdapat 3 langkah yang dilakukan pada kegiatan pembuka, inti yakni penerapan teknik dan penutup.

\section{Pengamatan}

Proses pengamatan proses pembelajaran dilakukan menggunakan lembar pengamatan yang diisi oleh observer. Selain mencentang, observer juga membuat catatan tentang hal-hal penting yang dapat mendukung data. Selain itu, juga dilakukan proses wawancara dengan mahasiswa berdasar katagori nilai yang mereka dapat.

\section{Refleksi}

Pada tahap ini peneliti melakukan refleksi terhadap pelaksanaan kegiatan pembelajaran di kelas. Hasil refleksi digunakan untuk melakukan perbaikan dan menganalisis keberhasilan di siklus I. berdasarkan data yang diperoleh, didapatkan hasil mahasiswa belum mencapai kriteria keberhasilan yangni rata-rata minimal 70 dan perubahan sikap siswa yang menunjukkan belum terlalu aktif dalam menganalisa, berdiskusi serta berbagi. Hampir setengah dari mahasiswa belum mencapai kriteria minimal Baik sehingga perlu dilanjutkan dan diperbaiki di siklus II. 


\section{Siklus II}

\section{Perencanaan}

Di siklus II proses perencanaan dilakukan dengan merumuskan perbaikan yang akan dilakukan dari siklus I, membuat RPP dengan materi derivational affixes dan inflectional affixes, menyiapkan instrument pengamatan berupa lembar pengamatan proses pembelajaran di kelas, wawancara dan tes untuk mengukur penguasaan kosakata mahasiswa.

\section{Pelaksanaan}

Siklus II dilaksanakan pada 18 \& 22 Desember 2017 dengan alokasi waktu 2x50 menit. Seperti di siklus I, peneliti juga memberikan teks untuk dianalisa oleh mahasiswa dengan judul "Wrap-Up of Second Language Reading: Teaching Issues" dan "Reading and Second Language Vocabulary Learning".

Pelaksanaan pembelajaran dengan melihat hasil refleksi siklus I yakni lebih mengondisikan siswa dan mengatur pembagian waktu sehingga mahasiswa dapat lebih fokus dan aktif lagi dalam proses pembelajaran.

\section{Pengamatan}

Proses pengamatan pembelajaran dilakukan menggunakan lembar pengamatan yang diisi oleh observer. Selain mencentang, observer juga membuat catatan tentang hal-hal penting yang dapat mendukung data.

\section{Refleksi}

Pada tahap ini, peneliti menyimpulkan bahwa proses pembelajaran dapat meningkatkan penguasaan kosakata dan perubahan sikap siswa menjadi lebih aktif.

\section{PEMBAHASAN}

Think Pair Share yang menurut Kagan (2009:14.8) terdiri dari 3 langkah yaitu Think (berfikir), Pair (berpasangan), dan Share (berbagi). Pada langkah Think (berpikir) mahasiswa diminta membaca sebuah teks secara individu dan mencermati isi bacaan. Selain itu, mereka juga menganalisa kosakata yang dianggap sulit, kosakata berimbuhan serta memaknai kosakata tersebut berdasarkan konteks kalimat tanpa melihat kamus. Selain itu, mereka harus mampu untuk membedakan imbuhan derivational dan inflectional sehingga memudahkan mereka menentukan kelas kata untuk derivational. Memahami kelas kata memudahkan mereka dalam menafsirkan arti sebab imbuhan dapat menentukan arti yang tepat dalam suatu kosakata. "Think time" menurut Kagan (2009:8.9) merupakan langkah yang sangat penting karena ketika proses berfikir mereka meningkatkan kualitas respon dan lebih mendorong aktif berpartisipasi dalam menuangkan ide dari diri mereka sendiri. Berhubungan dengan peningkatan penguasaan kosakata Bahasa Inggris, menurut Hudson (2007:227) kosakata merupakan kunci dalam bahasa dan pemerolehannya. Dari permyataan ini, jika seseorang ingin mahir dalam menggunakan bahasa maka kunci utamanya adalah menguasai kosakata. Oleh sebab itu, target keberhasilan dari penelitian ini adalah mahasiswa tidak hanya mampu menyebutkan kosakata berdasar jenisnya maupun kelas katanya, namun juga mampu mengaplikasikannya dalam kalimat yang benar. Pada proses Thinking (berfikir), mahasiswa tidak hanya membaca dan 
menerka isi, namun juga menganalisa kosakata sulit, berimbuhan, jenis serta arti secara individu. Hal ini meningkatkan kemampuan berfikir dalam menggali pemahaman mereka tentang kosakata Bahasa Inggris tanpa mengandalkan kamus. Dengan menerka arti dari suatu kosakata mereka diajak untuk lebih kritis dalam menganalisa kosakata lain dalam teks terutama di dalam kalimat yang berhubungan.

Langkah selanjutnya adalah Pair (berpasangan) dimana mahasiswa diminta untuk berhitung 1-5 dan mereka yang mendapat angka yang sama bergabung menjadi satu kelompok. Sehingga satu kelompok terdiri dari 5 orang. Di dalam kelompok, mereka saling mengoreksi hasil yang telah dianalisa teman dalam satu anggota kelompoknya (peer editing) dengan memastikan di dalam kamus. Kagan (2009:4.1) menyatakan bahwa manfaat dari bekerja kelompok adalah saling membantu dalam pekerjaan serta menumbuhkan aktivitas saling mendorong, mengajarkan dan memuji. Mahasiswa akan saling mengajari satu sama lain atau mereka yang lebih paham dapat membenahi pekerjaan temannya dan memberi masukan alternative jawaban yang tepat. Selain itu, kegiatan berkelompok juga dilakukan dalam penggabungan seluruh kosakata yang dimiliki dari setiap anggota agar mereka mendapat porsi dan pengetahuan kosakata yang sama.

Langkah yang terakhir adalah Share (berbagi). Proses ini dilakukan mahasiswa dengan saling menyebutkan kosakata yang mereka dapatkan beserta artinya dan hal itu juga dilakukan oleh kelompok lain. Sehingga semua dapat saling menambahkan dan mengoreksi hasil kosakata dari kelompok lain. Dalam hal ini, mahasiswa akan saling bertukar pemahaman mereka tentang kosakata yang mereka temukan dan mendapat kosakata yang lebih banyak dalam waktu singkat. Selain itu, untuk memastikan penguasaan mereka terhadap kosakata yang mereka dapat, maka mereka diminta untuk membuat kesimpulan dari bacaan dengan bantuan kosakata yang telah di diskusikan.

Sejalan dengan hal tersebut diatas, hasil tes yang dilakukan pada siklus I menunjukkan bahwa rata-rata mahasiswa sudah mampu mengubah kosakata berimbuhan dengan tepat sesuai dengan konteks kalimat dengan hasil capaian rata-rata 60 dan terdapat 50\% mahasiswa mendapat kriteria Baik atau sejumlah 13 mahasiswa. 1 mahasiswa dengan kriteria Sangat Baik atau sebesar 3,85\%. Dengan capaian tersebut, maka dilanjutkan ke siklus ke II dengan hasil yang meningkat yakni rata-rata kelas sebesar 71,15 . Terdapat $42,31 \%$ mahasiswa dengan katageri Baik dan 19,23 mendapat katagori Sangat Baik. Sehingga rata-rata pada siklus II sudah mencapai kriteria kesuksesan yang ditetapkan.

Selain hasil tes yang digunakan, lembar observasi menunjukkan perubahan perilaku mahasiswa di kelas setelah diaplikasikan Teknik Think-PairShare. Pada siklus 1 dan 2 ditemukan bahwa siswa lebih aktif dalam kegiatan pembelajaran dari pada sebelum digunakan Teknik ini di kelas. Mereka lebih banyak berpartisipasi dalam penguasaan materi karena proses pembelajaran berpusat pada mahasiswa. Mereka juga menunjukkan sikap antusias dengan penjelasan pengajar dengan menjawab pertanyaan yang dilemparkan. Di siklus pertama hanya ada beberapa mahasiswa yang menjawab pertanyaan dengan lantang, sedangkan di siklus kedua terlihat mereka lebih bersemangat dalam menjawab dan mengungkapkan ide tentang pertanyaan yang diajukan. Di kegiatan Think (berfikir) di siklus pertama mahasiswa masih terlihat kesulitan dalam 
menganalisa teks dan menentukan arti berdasarkan konteks. Hal ini dapat dilihat dengan seringnya mereka bertanya kepada pengajar. Sedangkan di siklus ke 2 sudah terlihat perbedaan sikap dimana mereka lebih serius menganalisa teks beserta artinya sehingga siswa melatih kemandirian mereka dalam memecahkan suatu masalah telah timbul. Keaktifan mahasiswa juga terlihat pada kegiatan berdiskusi dengan kelompok. Pada siklus 1 kondisi kelas belum terlalu kondusif namun mereka sudah aktif dalam mengoreksi hasil analisa teman sekelompoknya (peer editing) serta antusias mencari alternative jawaban yang tepat di dalam kamus. Pada siklus ke 2 dengan manajemen pengaturan waktu dimana setiap kegiatan mahasiswa dibatasi waktu agar tidak habis pada satu kegiatan, sehingga keadaan kelas lebih kondusif. Mereka lebih terfokus pada koreksi dan saling menambahkan kosakata yang penting untuk diketahui. Selain itu, mereka juga menganalisa kelas kata dan jenis kosakata dengan teliti dan seksama. Selanjutnya, pada proses sharing (berbagi) mereka dengan semangat saling bertukar kosakata yang mereka dapatkan. Sehingga semua mahasiswa yang ada di kelas memiliki kosakata yang sama dengan saling menambahkan. Di siklus 1 proses bertukar kosakata ini membuat kelas sedikit gaduh, namun di siklus ke 2 lebih kondusif dan mereka terlihat aktif. Kemudian mereka juga membaca kembali teks dan membuat rangkuman isi menggunakan kalimat sederhana dengan bantuan kosakata yang telah ada. Di siklus 1 dan 2 mahasiswa tidak terlalu memiliki masalah dalam merangkum dikarenakan terbantu oleh kosakata yang telah mereka temukan. Penggunaan Teknik Think Pair Share selain dapat meningkatan kosakata pada mahasiswa juga dapat mengubah perilaku menjadi lebih kritis berfikir, aktif berdiskusi, saling membantu di peer editing, semangat saling bertukar dan memudahkan dalam penyimpulan kalimat.

Hasil wawancara pada siklus 1 dan 2 menunjukkan perubahan positif bagi mahasiswa. Terdapat lima pertanyaan yang diajukan di setiap siklus yang meliputi: (1) kesulitan yang dihadapi mahasiswa dalam mempelajari kosakata, (2) strategi yang digunakan pengajar dapat membantu dalam menguasai kosakata, (3) mudah atau tidak mempelajari kosakata setelah menggunakan teknik di pembelajaran, (4) kesan mahasiswa setelah mengikuti pembelajaran, dan (5) perubahan yang terjadi setelah mengikuti pembelajaran. Jawaban-jawaban yang diberikan sudah menunjukkan bahwa mahasiswa terbantu dengan teknik ThinkPair-Share yang diaplikasikan dalam pembelajaran. Terbukti dengan hasil wawancara yang dilakukan dengan mahasiswa yang mendapat hasil bahwa teknik Think-Pair-Share dapat membantu mereka dalam menguasai kosakata.

\section{KESIMPULAN}

Kesimpulan dari hasil penelitian ini adalah Teknik Think Pair Share dapat meningkatkan penguasaan kosakata Bahasa Inggris pada mahasiswa semester 1 Program Pendidikan Bahasa Inggris Universitas Nahdlatul Ulama Blitar. Penelitian ini dilakukan melalui 2 siklus dimana setiap siklus terdiri dari 2 pertemuan. Peneliti juga memberikan tes tertulis kepada mahasiswa untuk mengukur kemampuan penguasaan mereka. Selain proses berkelompok, mahasiswa melalui proses Think dimana mereka diminta untuk berfikir, menganalisa teks berdasar kata-kata sulit dan kata berimbuhan. Mereka juga diminta untuk menyebutkan kelas kata lain dari kata yang berimbuhan sehingga memudahkan mereka dalam menyusun kalimat dengan benar. Teknik ini membuat mahasiswa lebih aktif dalam berdiskusi dalam menemukan kata yang dianggap sukar serta kata-kata yang mengandung imbuhan. Dalam meningkatkan penguasaan kosakata

153 BRILIANT: Jurnal Riset dan Konseptual Volume 3 Nomor 2, Mei 2018 
Bahasa Inggris, teman anggota dalam kelompok juga membantu untuk mengoreksi (peer editing) hasil kosakata yang didapat oleh temannya. Selain itu, Teknik ini membuat mahasiswa lebih memiliki lebih banyak kosakata dari penggabungan yang didapat tidak hanya dalam anggota kelompok namun dari kelompok lain pula. Keberhasilan itu juga dapat dilihat dari hasil tes yang didapatkan di siklus I yakni dengan rata-rata 60 dan terdapat 50\% mahasiswa mendapat kriteria Baik atau sejumlah 13 mahasiswa. 1 mahasiswa dengan kriteria Sangat Baik atau sebesar 3,85\%. Di siklus ke II dengan hasil yang meningkat yakni rata-rata kelas sebesar 71,15. Terdapat $42,31 \%$ mahasiswa dengan katageri Baik dan 19,23 mendapat katagori Sangat Baik.

\section{SARAN}

Untuk guru Bahasa Inggris diharapkan: (1) menggunakan Teknik Think-PairShare di dalam kelas pada proses pembelajaran sebagai suatu metode untuk meningkatkan kosakata Bahasa Inggris, (2) pengajar diharapkan dapat mengelola waktu dan kelas sehingga tercipta suasana yang kondusif serta keefisienan waktu ketika proses berdiskusi dan sharing, (3) pengajar lebih dapat mengondisikan proses berkelompok sehingga semua anggota kelompok bersikap aktif, (4) terdapat penelitian tindakan kelas lain yang munggunakan Teknik Think-Pair-Share dengan materi dan tingkat Pendidikan yang berbeda. Untuk siswa disarankan untuk terus berlatih dalam meningkatkan penguasaan kosakata Bahasa Inggris mereka agar semua kemampuan dalam Bahasa Inggris lebih baik. Mereka dapat lebih aktif dan interaktif dalam proses pembelajaran dengan mengerjakan sungguh-sungguh teks yang diberikan. Selain itu, mereka dapat menggunakan langkah-langkah dalam Teknik Think-Pair-Share untuk membantu meningkatkan penguasaan kosakata.

\section{DAFTAR RUJUKAN}

Cahyono, Bambang Yudi dan Utami Widiati. 2011. The Teaching of English as a Foreign Language in Indonesia. Malang: State University of Malang Press.

Grabe, William. 2009. Reading in a Second Language: Moving from Theory to Practice. United States of America: Cambridge University Press

Hudson, Thom. 2007. Teaching Second Language Reading. UK: Oxford University Press

Kagan, Spencer Dr. \& Kagan, Miguel. (2009). Kagan Cooperative Learning. California: Kagan Publishing. 